\title{
Hydrochemical properties of ground water of Rahaliya-Ekhedhur region, west Razzaza lake, iraq
}

\author{
Moutaz Al-Dabbas ${ }^{1}$, Qusai Al-Kubaisi ${ }^{1}$, Tariq Hussein ${ }^{2}$ and Shahad Al- Qaraghuli ${ }^{3}$ \\ ${ }^{1}$ College of Science, University of Baghdad, Baghdad, Iraq \\ ${ }^{2}$ Building and Construction Engineering Department, University of Technology, Baghdad, Iraq \\ ${ }^{3} \mathrm{Al}$ Karkh University of Science, Baghdad, Iraq.
}

\begin{abstract}
Rahaliya - Ekhedur region is located to the west of Razzaza Lake (M.IRAQ). It is within the Salman - Rutba tectonic zones characterized by the existence of Abu Jir and Imam Ahmad bin Hashim Fault Systems. The major geological formations in the studied area consists of Tertiary and Quaternary deposits described from the oldest to the youngest as : Dammam, Euphrates, Nfayil and Injana, formations, and the slope of beds is less than one degree in the direction of east and northeast towards Al-Razzaza lake. To evaluate the hydrochemical properties and the quality groundwater samples were collected from 16 wells at different depths $80-120 \mathrm{~m}$, during April and October 2013. These samples have been chemically analyzed and the results indicated that the ground water is of mixed origin, very hard (TH ranging from 227.5 to $1032.8 \mathrm{ppm}$ ), having high pH values, while the Total Dissolved Solids (TDS) ranging from 1700 to $2750 \mathrm{mg} / 1$ so that the water is of brackish type. On the basis of the major cation and anion concentration the groundwater during April 2013 was of mixed Mg and $\mathrm{Na}-\mathrm{SO} 4$ group having two families which are $\mathrm{Na} 2 \mathrm{SO} 4$ family with $\mathrm{Na}+>\mathrm{Ca} 2+>\mathrm{Mg} 2+-\mathrm{SO} 42->\mathrm{Cl}->\mathrm{HCO} 3-$ and $\mathrm{MgSO} 4$ water family with $\mathrm{Mg} 2+>\mathrm{Ca} 2+>\mathrm{Na}+-\mathrm{SO} 42->\mathrm{Cl}->\mathrm{HCO} 3-$. While, the groundwater during October 2013 is of two groups ( $\mathrm{Na}-\mathrm{SO} 4)$ having two families which are (Na2SO4) family with $\mathrm{Na}+>\mathrm{Ca} 2+>\mathrm{Mg} 2+-$ SO42- $>\mathrm{Cl}->\mathrm{HCO} 3$-and $(\mathrm{MgSO} 4)$ water family with $\mathrm{Mg} 2+>\mathrm{Ca} 2+>\mathrm{Na}+-\mathrm{SO} 42->\mathrm{Cl}->\mathrm{HCO} 3-$. The second group was $\mathrm{Na}-\mathrm{Cl}$ with $\mathrm{Na}+>\mathrm{Mg} 2+>\mathrm{Ca} 2+-\mathrm{Cl}->\mathrm{SO} 42->\mathrm{HCO} 3-$ and $\mathrm{Na}+>\mathrm{Ca} 2+>\mathrm{Mg} 2+-\mathrm{Cl}->\mathrm{SO} 42->$ HCO3- . Therefore, the ground water in the region is not good for drinking due to high salinity and it is of Doubtful to unsuitable-Unsuitable for irrigation but it can be used to irrigate sensitive crops in areas.
\end{abstract}

\section{Introduction}

Water resources systems need to be operated to cope with variability of climate changes, mainly the expected changes in temperature and precipitation. There is great need for an emergency or water resources risk management practices. These water systems, traditionally, are designed on the assumption that the statistical characteristics of the hydro-meteorological processes are almost expected annually and on the long run. Several studies were conducted concerning the hydraulic characteristics and the hydrochemical analysis properties of the groundwater of Rahhalia, Shithatha or Ekhedhur [1], [2], [3]. But no one investigated all these locations together. Therefore, the area from Rahhalia to Ekhedhur is chosen for further deals of the hydrochemical analyses and future utilization of the groundwater (Fig. 1).

The chosen region is in central Iraq between Al-Anbar and Karbala governorates, to the west of the Razzaza Lake. The region is extending from Rahhalia to the Ekhedhur between latitudes $32^{\circ} 25^{\circ}-32^{\circ} 50^{\prime}$ North and longitudes $43^{\circ} 15^{\prime}-43^{\circ} 40^{\circ}$ East (Fig. 1). The region is characterized by arid climate of hot dry summer, cold dry winter with annual rainfallof $90 \mathrm{~mm}$ mainly during January to April and annual evaporation of $2954 \mathrm{~mm}$ (Table 1) [4]. The geology of study area represented by the tertiary sediments of different ages and rock units such as Dammam, Euphrates, Nfayil, Injana and Dibdiba formations. Quaternary sediments cover vast area near Al-Razzaza Lake which represented by gypcrete, inland sabkha, depression fill, flood plain and Aeolian sediments (Figure 1). The studied area has two fault systems, Abu Jir and Imam Ahmad bin Hashim which are deepening more than $150 \mathrm{~m}$ for the period before 
Miocene and its main trend is to the northwest southeast [5]. It is believed that the groundwater related to the same line, which extends to more than $10 \mathrm{~km}$ in width, [6]. Topography of the area has gentle slope terrains to the east towards Al-Razzaza Lake and the dip of the beds is less than one degree to the east and northeast with elevations of $65-35 \mathrm{~m}$. above mean sea level [7], (Figures 1 and 2). Because of geological nature of the study area, it is characterized by distinguished hydrogeology through the presence of the Abu Jir and Imam Ahmad bin Hashim fault systems. The hydrogeology situation depends on the nature of the structural, geological, type of formations, nature of the water bearing rocks and cavities [8]. The ground water aquifers are represented by three aquifers, (Tayarat UmmRadhuma), (Dammam - Euphrates) and Nifayil formations [2], [9].

The studied area is considered as a discharge area to AlRazzaza Lake, and the study area is considered to be one of the important areas due to the existence of several economic projects [10]. Two hydrogeological units were defined in the study area, unconfined and confined aquifers. The unconfined aquifer in the studied area is represented by the Euphrates - Nifayil formations [9], [11]. The Euphrates aquifer is characterized by the total dissolved solids ranging between 4000-6000 mg/l and the electrical conductivity ranges between 5000-7000 $\mu \mathrm{s} / \mathrm{cm}$, with sulphatic water type at Shithatha and Rahaliya localities [11].

The confined aquifers represented by the Dammam Formation which is one of the most vital aquifers in western Iraq. It is composed of variable carbonate rocks mainly limestone, dolomatic limestone and dolomite, with secondary It is characterized by the presence of cavities and canals in addition to fractures, fissures and joints, which cause the formation to have highest transmissivity and permeability, in most areas [11]. The Dammam aquifer is considered to be the main source of water in the area [12]. The aims of this study are to investigate the hydrochemical analyses and to evaluate the quality of ground water suitability for different purposes at Rahhalia - Ekhedhur area during April and October 2013.

\section{Materials and methods}

Sixteen wells have been chosen for this study distributed over all the area (Figure 1). Groundwater samples were selected from sixteen boreholes during April and October 2013 from Rahaliya to Ekhedhur region (Figure-1). The analysis of the concentration of cations $\left(\mathrm{K}^{+}, \mathrm{Na}^{+}, \mathrm{Mg}^{2+}\right.$, $\left.\mathrm{Ca}^{2+}\right)$ and anions $\left(\mathrm{Cl}^{-}, \mathrm{HCO}_{3}{ }^{-}, \mathrm{SO}_{4}{ }^{2-}\right)$ in addition to (Electric conductivity EC, Total Dissolved Salts, TDS and $\mathrm{pH}$ ) have been done in the chemical laboratory of the General Commission for Groundwater. The results of major ions, TDS, EC and $\mathrm{pH}$ were shown in Tables 1 and 2.

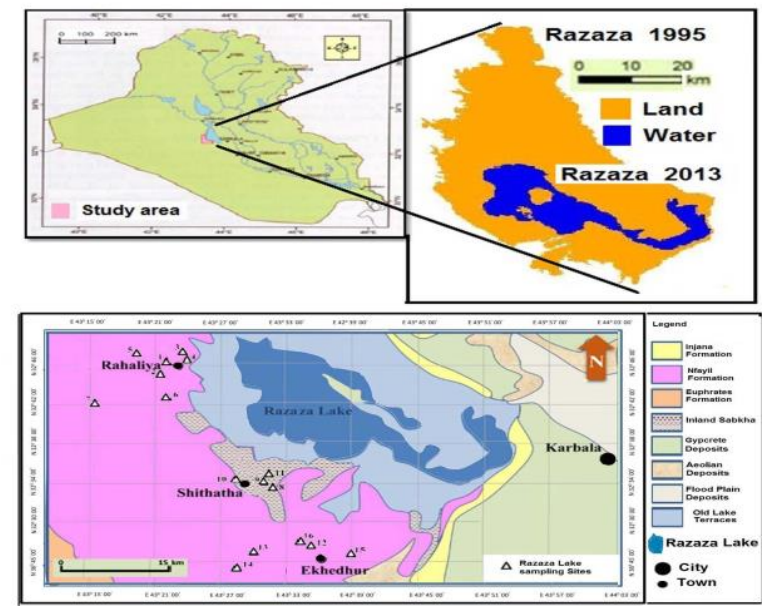

Fig. 1: Location and geological map of the study area.

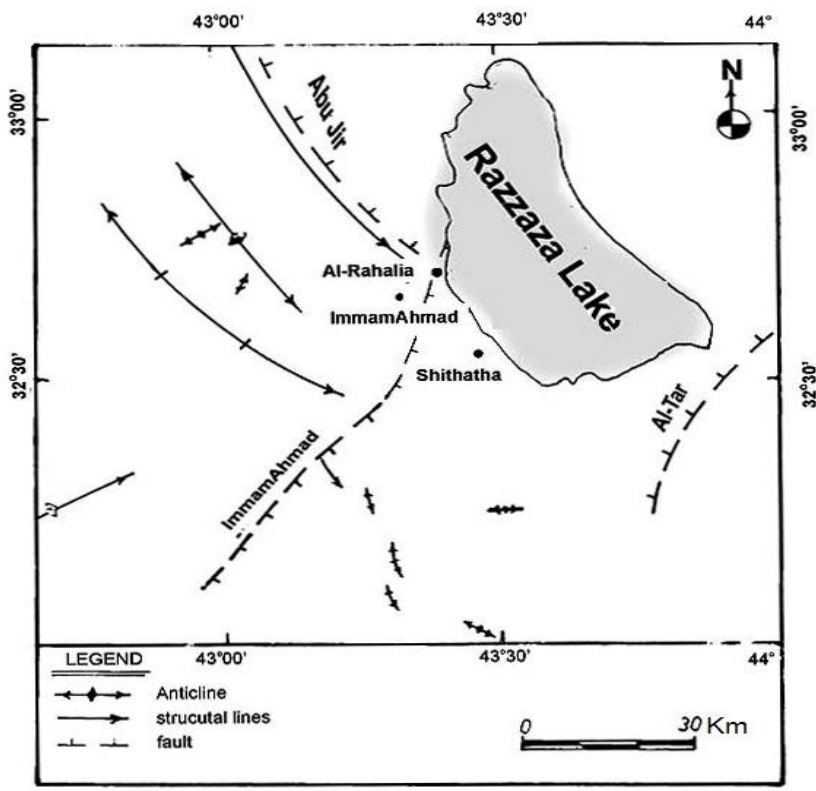

Fig. 2: Tectonic map of the study region (modified after [13]).

\section{Results and discussion}

The TDS of the groundwater is ranging from 1700 to 2420 ppm during April 2013 while October 2013 ranging from 1740 to $2750 \mathrm{ppm}$ (Tables 1 and 2).The EC value is ranging from 2520 to $3710 \mu \mathrm{s} / \mathrm{cm}$ during April 2013 while during October 2013 ranging from 2560 to $3850 \mu \mathrm{s} / \mathrm{cm}$.

Applying three classifications of water for salinity values for both periods reflect slightly-brackish water (Tables 1 and 2) [4], [8], [14]. The $\mathrm{pH}$ values ranging from 7.08 to 7.61 during April 2013 while during October 2013 ranging from 7.11 to 7.80 . 
The total hardness $(\mathrm{TH})$ was ranging from 227.5 to 772.9 ppm during April 2013 while in October 2013 it was ranging from 338.4 to $1032.8 \mathrm{ppm}$ ) and indicated very hard water.

Previous study [14] examined the relationship between electrical conductivity (EC $\mu \mathrm{S} / \mathrm{cm}$ ) and water mineralization. It can be concluded that the type of spring and Al-Razzaza Lake waters indicate to excessively mineralized water.

Comparison of TDS values for both periods with three classifications of water was classified as slightly-brackish water not useful for drinking [4], [14]. Applying Sulin's [15] classification, the ground water samples fall in the zone of $\mathrm{A}<1$ that represents marine water in semi confined aquifer and in the zone of $\mathrm{B}<1$ that represent meteoric origin of $\mathrm{Na}+\mathrm{K}$ - Sulphate .

According to Schoeller [4], classification the groundwater samples shows that the groups are $\mathrm{SO}_{4}$ and $\mathrm{Cl}$ and the families are $\mathrm{Na}-\mathrm{SO}_{4}, \mathrm{Mg}-\mathrm{SO}_{4}, \mathrm{Ca}-\mathrm{SO}_{4}, \mathrm{Na}-$ $\mathrm{Cl}$ for wet and dry periods. While according to Piper's [4], classification the groundwater samples falls in e class and some of these samples fall in $\mathrm{g}$ - class [4]. The application of Piper's diagram [4] shows that all water samples have non carbonate hardness (secondary salinity $>50 \%$ ). Moreover, all the water samples have total hardness value $>300$ and according to Todd's classification [4]. So, all the water samples were not useful for drinking. The result of using Hassan, et al, [16], method to classify the ground water of Rahaliya Ekhedhur area during April and October 2013, and identifying their water types are shown in Tables 1 and 2 . The Rahaliya and Ekhedhur groundwater have clearly indicated that the sulphate and chloride groups are dominant. During April 2013, the sulphate group with two families (sulphate -sodium and sulphatemagnesium) where the first family with one major water type $\mathrm{rNa}>\mathrm{rCa}>\mathrm{rMg}$; $\mathrm{SO} 4>\mathrm{rCl}$, while the second family with two water types $\mathrm{rMg}>\mathrm{rCa}>\mathrm{rNa}$; $\mathrm{rSO} 4>\mathrm{rCl}$ and $\mathrm{rMg}>\mathrm{rNa}>\mathrm{rCa}$; $\mathrm{rSO} 4>\mathrm{rCl}$ water type. The chloride group contains one major family (chloride -sodium family) and one water type which is $\mathrm{rNa}>\mathrm{rMg}>\mathrm{rCa}$; $\mathrm{rCl}>\mathrm{rSO} 4$ water type. While during October 2013, the sulphate group with two families (sulphate -sodium and sulphate- calcium) the first family with two water types $\mathrm{rNa}>\mathrm{rCa}>\mathrm{rMg}$; $\mathrm{SO} 4>\mathrm{rCl}$ and $\mathrm{rNa}>\mathrm{rMg}>\mathrm{rCa} ; \mathrm{rSO} 4>\mathrm{Cl}$, while the second family with one major water type $\mathrm{rCa}>\mathrm{rMg}>\mathrm{rNa}$; $\mathrm{rSO} 4>\mathrm{Cl}$ water type. The chloride group contains one major family (chloride -sodium family) and with two water types $\mathrm{rNa}>\mathrm{rMg}>\mathrm{rCa} ; \mathrm{rCl}>\mathrm{rSO} 4$ and $\mathrm{rNa}>$. $\mathrm{rCa}>\mathrm{rMg} ; \mathrm{rCl}>\mathrm{SO} 4$.

This variation can be attributed to the lithological and mineralogical contents of the geological formation [16]. Al-Basrawi, [2], concluded that the main groundwater recharge sources at the west and south west of Al-Razaza lake are from the subsurface water flow from the west and south west catchment of the studied area which flow through fractures and subsurface channels that affected by the fault systems of the area represented by Abu Jeir and Emam Ahmad faults (Fig.2). Moreover, the ground water is similar to the deep groundwater of Tayarat aquifer of Chloride group with ChlorideSodium family that affect the Dammam and Euphrates aquifers of Sulphate group with Sulphate- Sodium and Sulphate- Magnesium families. The rainfall represents water availability element which is vital for the water surplus occurred in the study area and it is the most important climate elements in the water balance and aquifer recharge. The increase in precipitation has an impact on the groundwater and transmission of material from the upper parts to the lower parts. The average mean annual rainfall in $\mathrm{mm}$ for ten years intervals indicate that there were a remarkable decrease in the amount of rainfall for years 1992-2013 that reflected the regional climatic change as shown for Karbala meteorological station, the average mean annual rainfall in $\mathrm{mm}$ for ten years intervals decrease from $90 \mathrm{~mm}$ for the period $1992-2001$ to about $71 \mathrm{~mm}$ for the period 2002- 2013 [4].

\subsection{Groundwater suitability for different purposes}

The groundwater chemical analyses of two periods reflected unsuitability for drinking according to Iraqi standards and World Health Organization standard [4]. The ground waters are good or acceptable for animal drinking according to Altoviski, Crist and Lowery and Ayers and Westcot [4], but they were not good for industrial purposes according to Hem [4]. Also, they are suitable for building purposes according to Altoviski [4] and doubtful according to Ayers and Westcot [4] and Don [8] classifications for irrigation purpose.

\section{Conclusions}

1- The examined groundwater is classified as slightlybrackish, very hard water and can be concluded that the type water indicate excessively mineralized water. 2- The groundwater is of mixed $\mathrm{Mg}$ and $\mathrm{Na}-\mathrm{SO}_{4}$ group having two families which are $\left(\mathrm{Na}_{2} \mathrm{SO}_{4}\right)$ and $\left(\mathrm{MgSO}_{4}\right)$.

3- The results indicate two types, the first is marine water and the second is meteoric water. Marine origin indicates deep origin because of existence of a different pressure caused to make a vertical flow of groundwater.

4- The ground water in the region were not good for drinking and it is Doubtful to unsuitable-Unsuitable for irrigation whereas it can be used to irrigate sensitive crops. Also, it is not suitable for industrial and suitable for building purposes. 


\section{References:}

1. Consrtium, 1977. Water development projects, Western Desert Block 7; Hydrogeological explorations and Hydrotechnical works, Climatology and Hydrology, Yugoslavia Final Report Vol.1, Republic of Iraq, Directorate of Western Desert Development Projects, (Unpub.).

2. Al-Basrawi, N H., 1996, Hydrogeology of Razzaza Lake, Unpub. Ph.D. Thesis, College of Science ,University of Baghdad. Iraq. (in Arabic). P.128.

3. Jassim R. and Al-Zubaidi A. 2013,Hydrochemical assessment of water resources southern part of AlRazzazah Lake and surroundings, Karbala area, central Iraq, Iraqi bulletin of Geology and Mining, Vol.9, No.2, pp 81-95.

4. Al- Qaraghuli S. A. ,2014, Hydrogeological and Hydrochemical Study of Al-Rahaliya -Al-Ekhedhur Area, Unpub. M.Sc. Thesis, College of Science, University of Baghdad.

5. Barazanji, M.A., and Yasi, A.I., (1987): Geophysical Study of Habbania- Razzaza area, J. Water Reso., Vol. 6, No.2.

6. Abbass, M,J:, and AL-Khatib, H.H;(1982) : Complex Geophysical Interpertation of Hit-Abu-Jir, Shithatha area, SOM Lib, Rep. No. 1247, 34P.

7. Al-Meheidi, H., Vejlupek, M., and Yacoub, S. Y., 1975: The regional geological mapping of Shithatha Habbaniyah area. GEOSURV, int. rep. No. 697.

8. Don, C.M., 1995: A grows guide to water quality. University college station, Texas. P. 601-609.

9. Al- Fatlawi , A.N. (2000): Hydrochemical study of Shithatha area under white valley. M.Sc. Thesis. Collage of science. University of Baghdad. (In Arabic). P.113.

10. Hassan, A. H. and al Kubaisi, Q. Y., 2002: The fourth axis and the third subaxis, natural recharge for the ground water in the western desert. Second part. PP. 308-310.

11. Al-Jiburi, H. K., and Al-Basrawi, N.H., 2007: Geology of the Iraqi western desert, Iraqi Bulletin of Geology and Mining, (GEOSURV, Iraq), P. 169.

12. Al-Jiburi, H.K., and Al-Basrawi, N. H., 2014: Hydrogeological map of Iraq, scale $1: 1000000,2^{\text {nd }}$ edition, Iraqi Bulletin of Geology and Mining, (GEOSURV, Iraq), vol.10, No.2, P. 29.

13. Sissakian, V., Ibrahim, E., Ibrahim, F., \& Al-Ani, N., 2000.Geologic Map of Iraq, 3rd.edition, GEOSURV, Baghdad, Iraq.

14. Detay, M., 1997: Water Wells- implementation, maintenance and restoration, John Wiley and Sons, London, P. 379.

15. Sullin, V.A., 1946, Oil water in the system of natural groundwater, Gostopichezdat, Moscow USSR, 215p.vol. 30, No. 1, P. 37-45.
16. Hassan, A.H., Al-Din, T.S. and Al-Sayyab, A., (1988) The(SS) hydrochemical model, Iraqi J. Sci.,V. 29 ,No. $1 \& 2$ pp. 109-121. 
Table 1. Groundwater properties in the wet period April, 2013.

\begin{tabular}{|l|l|l|l|l|l|l|l|l|l|l|}
\hline $\begin{array}{l}\text { Well } \\
\text { No }\end{array}$ & $\begin{array}{l}\text { Na+K } \\
\text { epm } \\
(\%)\end{array}$ & $\begin{array}{l}\mathrm{Mg} \\
\text { epm } \\
(\%)\end{array}$ & $\begin{array}{l}\mathrm{Ca} \\
\text { epm } \\
(\%)\end{array}$ & $\begin{array}{l}\mathrm{Cl} \\
\mathrm{epm} \\
(\%)\end{array}$ & $\begin{array}{l}\text { SO4 } \\
\text { epm } \\
(\%)\end{array}$ & $\begin{array}{l}\mathrm{HCO} 3 \\
\text { epm } \\
(\%)\end{array}$ & $\begin{array}{l}\text { TDS } \\
\mathrm{ppm}\end{array}$ & $\begin{array}{l}\mathrm{EC} \\
\mu \mathrm{s} / \mathrm{cm}\end{array}$ & $\mathrm{pH}$ & $\begin{array}{l}\text { T.H } \\
(\mathrm{ppm})\end{array}$ \\
\hline 1 & 61.57 & 19.96 & 18.45 & 54.67 & 32.24 & 13.08 & 2137 & 3710 & 7.31 & 648.9 \\
\hline 2 & 69.27 & 14.13 & 16.58 & 32.31 & 61.09 & 6.59 & 1740 & 2570 & 7.12 & 276.9 \\
\hline 3 & 72.09 & 12.50 & 15.38 & 36.31 & 47.86 & 15.82 & 1848 & 2760 & 7.08 & 320.8 \\
\hline 4 & 78.90 & 8.38 & 12.7 & 36.85 & 42.35 & 20.78 & 1860 & 2560 & 7.15 & 227.5 \\
\hline 5 & 45.97 & 18.37 & 35.64 & 38.04 & 48.23 & 13.71 & 1755 & 2520 & 7.30 & 604.3 \\
\hline 6 & 32.03 & 35.99 & 32.58 & 35.42 & 58.96 & 5.61 & 1932 & 2650 & 7.40 & 655.1 \\
\hline 7 & 32.7 & 43.97 & 32.32 & 35.27 & 59.09 & 5.61 & 1820 & 2600 & 7.50 & 648.5 \\
\hline 8 & 31.41 & 36.5 & 32.08 & 35.33 & 59.49 & 5.17 & 1932 & 2550 & 7.61 & 687.2 \\
\hline 9 & 31.26 & 36.59 & 32.16 & 35.36 & 59.4 & 5.23 & 1700 & 2560 & 7.16 & 687.2 \\
\hline 10 & 34.22 & 34.37 & 31.39 & 35.59 & 59.14 & 5.55 & 1919 & 2650 & 7.31 & 652.6 \\
\hline 11 & 42.2 & 27.93 & 29.79 & 41.67 & 45.25 & 13.07 & 1872 & 2540 & 7.15 & 772.9 \\
\hline 12 & 47.51 & 17.84 & 34.63 & 37.43 & 47.58 & 14.98 & 1723 & 2560 & 7.34 & 604.3 \\
\hline 13 & 74.40 & 11.57 & 14.01 & 40.25 & 42.47 & 17.27 & 2000 & 2670 & 7.34 & 320.9 \\
\hline 14 & 55.47 & 24.29 & 20.24 & 49.38 & 39.13 & 11.47 & 2420 & 3000 & 7.31 & 685.8 \\
\hline 15 & 42.00 & 18.61 & 35.38 & 37.5 & 47.52 & 14.96 & 1812 & 3020 & 7.21 & 620 \\
\hline 16 & 74.59 & 11.39 & 14.02 & 40.44 & 42.31 & 17.24 & 2172 & 2920 & 7.19 & 320.9 \\
\hline
\end{tabular}

Table 2. Groundwater properties in the dry period October, 2013

\begin{tabular}{|l|l|l|l|l|l|l|l|l|l|l|}
\hline $\begin{array}{l}\mathrm{Nelll} \\
\text { No }\end{array}$ & $\begin{array}{l}\mathrm{Na}+\mathrm{K} \\
\mathrm{epm} \\
(\%)\end{array}$ & $\begin{array}{l}\mathrm{Mg} \\
\text { epm } \\
(\%)\end{array}$ & $\begin{array}{l}\mathrm{Ca} \\
\text { epm } \\
(\%)\end{array}$ & $\begin{array}{l}\mathrm{Cl} \\
\text { epm } \\
(\%)\end{array}$ & $\begin{array}{l}\text { SO4 } \\
\text { epm } \\
(\%)\end{array}$ & $\begin{array}{l}\mathrm{HCO} \\
\text { epm } \\
(\%)\end{array}$ & $\begin{array}{l}\text { TDS } \\
\text { ppm }\end{array}$ & $\begin{array}{l}\mathrm{EC} \\
\mu \mathrm{s} / \mathrm{cm}\end{array}$ & $\mathrm{pH}$ & $\begin{array}{l}\text { T.H } \\
(\mathrm{ppm})\end{array}$ \\
\hline 1 & 56.37 & 21.59 & 22.03 & 55.61 & 31.28 & 13.09 & 2350 & 3850 & 7.20 & 839.4 \\
\hline 2 & 69.42 & 13.3 & 17.26 & 36.56 & 51.29 & 12.13 & 1740 & 2560 & 7.21 & 339.8 \\
\hline 3 & 70.00 & 14.23 & 15.37 & 40.46 & 42.39 & 17.13 & 2204 & 2900 & 7.11 & 389.5 \\
\hline 4 & 69.5 & 12.47 & 17.53 & 36.55 & 51.19 & 12.24 & 2226 & 2950 & 7.22 & 338.4 \\
\hline 5 & 37.07 & 31.90 & 31.01 & 37.37 & 56.75 & 5.67 & 2100 & 2800 & 7.21 & 632.5 \\
\hline 6 & 45.1 & 23.58 & 31.40 & 41.13 & 44.84 & 14.02 & 2305 & 2800 & 7.80 & 978.1 \\
\hline 7 & 45.46 & 23.30 & 31.22 & 40.46 & 44.53 & 14.49 & 2220 & 2800 & 7.3 & 962.4 \\
\hline 8 & 44.34 & 23.26 & 32.37 & 33.39 & 51.62 & 10.97 & 2238 & 3670 & 7.36 & 1032.8 \\
\hline 9 & 71.81 & 12.65 & 15.53 & 40.25 & 42.47 & 17.27 & 2000 & 3670 & 7.40 & 366.4 \\
\hline 10 & 27.33 & 33.31 & 39.34 & 43.50 & 51.52 & 4.96 & 2260 & 2750 & 7.20 & 852.1 \\
\hline 11 & 38.99 & 31.5 & 29.49 & 53.96 & 37.35 & 8.68 & 2228 & 2700 & 7.20 & 979.6 \\
\hline 12 & 36.91 & 31.99 & 31.09 & 35.09 & 59.14 & 5.55 & 2000 & 2750 & 7.30 & 632.4 \\
\hline 13 & 41.95 & 24.58 & 33.53 & 35.74 & 53.18 & 11.07 & 2450 & 3480 & 7.22 & 972.5 \\
\hline 14 & 48.24 & 22.24 & 29.51 & 29.75 & 46.32 & 23.05 & 2750 & 3260 & 7.25 & 813.7 \\
\hline 15 & 44.21 & 23.11 & 33.47 & 40.42 & 45.17 & 14.4 & 2113 & 2750 & 7.25 & 802 \\
\hline 16 & 70.94 & 13.79 & 15.24 & 40.46 & 42.39 & 17.13 & 2476 & 3260 & 7.11 & 389.6 \\
\hline
\end{tabular}


Table 3. Rahaliya- Shithatha groundwater classification for the wet period April, 2013 according to according to [16]

\begin{tabular}{|c|c|c|c|c|c|c|}
\hline & Family & Group & Index & Water type & Spring No. & $\%$ \\
\hline 1 & $\begin{array}{l}\text { Sulphate- } \\
\text { Sodium }\end{array}$ & \multirow[t]{3}{*}{ Sulphate } & $23 ; 32$ & $\begin{array}{l}\mathrm{rNa}>. \mathrm{rCa}>\mathrm{rMg} ; \mathrm{rSO} \\
4>\mathrm{rCl}\end{array}$ & $\begin{array}{l}2,3,4,5,11,12, \\
13,15,16\end{array}$ & $56.25 \%$ \\
\hline \multirow[t]{2}{*}{$\begin{array}{l}2 \\
3\end{array}$} & \multirow[t]{2}{*}{$\begin{array}{l}\text { Sulphate- } \\
\text { Magnesium }\end{array}$} & & $53 ; 32$ & $\begin{array}{l}\mathrm{rMg}>\mathrm{rCa}>\mathrm{rNa} \\
\mathrm{rSO} 4>\mathrm{Cl}\end{array}$ & $6,8,9$ & $18.75 \%$ \\
\hline & & & $33 ; 32$ & $\begin{array}{l}\mathrm{rMg}>\mathrm{rNa}>\mathrm{rCa} ; \mathrm{rSO} \\
4>\mathrm{Cl}\end{array}$ & 7,10 & $12.5 \%$ \\
\hline 4 & $\begin{array}{l}\text { Chloride- } \\
\text { Sodium }\end{array}$ & Chloride & $13 ; 12$ & $\begin{array}{l}\mathrm{rNa}>\mathrm{rMg}>\mathrm{rCa} ; \mathrm{rCl}> \\
\mathrm{SO} 4\end{array}$ & 1,14 & $12.5 \%$ \\
\hline
\end{tabular}

Table 4. Rahaliya- Shithatha groundwater classification for the dry period October, 2013 according to [16]

\begin{tabular}{|c|c|c|c|c|c|c|}
\hline & Family & Group & Index & Water type & Spring No. & $\%$ \\
\hline 1 & \multirow[t]{2}{*}{$\begin{array}{l}\text { Sulphate- } \\
\text { Sodium }\end{array}$} & \multirow[t]{3}{*}{ Sulphate } & $13 ; 32$ & $\begin{array}{l}\mathrm{rNa}>\mathrm{rMg}>\mathrm{rCa} ; \mathrm{rSO} 4> \\
\mathrm{Cl}\end{array}$ & 5,12 & $12.5 \%$ \\
\hline 2 & & & $23 ; 32$ & $\begin{array}{l}\mathrm{rNa}>. \mathrm{rCa}>\mathrm{rMg} ; \mathrm{rSO} 4> \\
\mathrm{rCl}\end{array}$ & $\begin{array}{l}2,3,4,6,7,8,9,13,1 \\
4,15,16\end{array}$ & $68.75 \%$ \\
\hline 3 & $\begin{array}{l}\text { Sulphate- } \\
\text { Magnesium }\end{array}$ & & $63 ; 32$ & $\begin{array}{l}\mathrm{rCa}>\mathrm{rMg}>\mathrm{rNa} \\
\mathrm{rSO} 4>\mathrm{Cl}\end{array}$ & 10 & $6.25 \%$ \\
\hline 4 & \multirow[t]{2}{*}{$\begin{array}{l}\text { Chloride- } \\
\text { Sodium }\end{array}$} & \multirow[t]{2}{*}{ Chloride } & $13 ; 12$ & $\begin{array}{l}\mathrm{rNa}>\mathrm{rMg}>\mathrm{rCa} \\
\mathrm{rCl}>\mathrm{SO} 4\end{array}$ & 11 & $6.25 \%$ \\
\hline 5 & & & $23 ; 12$ & $\begin{array}{l}\mathrm{rNa}>. \mathrm{rCa}>\mathrm{rMg} \\
\mathrm{rCl}>\mathrm{SO} 4\end{array}$ & 1 & $6.25 \%$ \\
\hline
\end{tabular}

